\title{
REVISANDO OS CONCEITOS DE CELULAR E EDUCAÇÃO: A UTILIZAÇÃO DO DISPOSITIVO MÓVEL COMO RECURSO PE- DAGÓGICO NO PARANÁ DE ACORDO COM A LEI ESTADUAL
}

\author{
$N^{0}$. 18.118/2014-PR
}

\section{REVIEWING CONCEPTS OF MOBILE AND EDUCATION: USING THE MOBILE DEVICE AS A PEDAGOGICAL RESOURCE IN PARANÁ ACCORDING TO STATE LAW Nº 18.118 / 2014-PR}

DOI: http://dx.doi.org/10.5965/1984317815042019058

André Crepaldi

Instituto Federal do Paraná

crepaldi fm@hotmail.com

\begin{abstract}
RESUMO
O presente artigo tem como tema, celular e educação e, como recorte, o uso do dispositivo móvel como recurso pedagógico no estado do Paraná. O objetivo desta pesquisa é discutir de que modo o celular pode ser utilizado como recurso pedagógico eficiente em sala de aula no estado do Paraná, de acordo com a lei estadual $\mathrm{n}^{\circ}$ 18.118/2014-PR, considerando que, na maioria das vezes, é proibidoo uso nas escolas do estado. Para isso, adotou-se como estratégia metodológica o estudo de caso e pesquisa bibliográfica, realizada por meio de consultas em artigos científicos, dissertações de mestrado e tese de doutorado, com base no banco de dados da Capes. Conclui-se que utilizar o celular em sala de aula demanda mais força de vontade e interesse do professor, uma vez que seu uso é permitido pela legislação do estado, desde que apropriado para fins pedagógicos. O celular pode ser um excelente instrumento pedagógico, capaz de potencializar o processo de ensino e aprendizagem.
\end{abstract}

Palavras-Chave: Celular. Tecnologia. Professor. Educação.

\begin{abstract}
The present article has as its theme, cell phone and education and, as a cut, the use of the mobile device as an pedagogical instrument in the state of Paraná. The objective of this research is to discuss how the cell phone can be used as an efficient pedagogical resource in the classroom in the state of Paraná, according to state law $n^{0} 18.118$ / 2014-PR, considering that, for the most part, it is prohibited use in state schools. For this, a case study and bibliographic research was carried out as a methodological strategy, through consultations in scientific articles, master's dissertations and doctoral thesis, based on the Capes database. It is concluded that using the cell phone in the classroom demands more willpower and teacher interest, since its use is allowed by state legislation, as long as appropriate for pedagogical purposes. The cell phone can be an excellent pedagogical tool, capable of enhancing the teaching and learning process.
\end{abstract}

Keywords: Cell phone. Technology. Teacher. Education. 


\section{INTRODUÇÃO}

Pensar a educação requer atenção além dos meios tradicionais de ensino, quadro, giz e livro, baseado no processo de emissão de informação pelo professor e recepção pelo aluno. Durante muito tempo o professor foi detentor do saber e sua autonomia,maioritária, nesse contexto, cabia somente ao aluno a recepção de informação, sem espaço e participação.

A sociedade, assim como as escolas, vemsofrendo alterações, devido a evoluçãode tecnologias digitais. Embora, muitas instituições de ensino no Brasil ainda são precárias, no que se refere a dispositivos tecnológicos e acesso à internet, o tema requer uma atenção no que se refere ao uso do celular na prática pedagógica.

A internet possibilitou ao aluno navegar com inquietação e curiosidade. Além de todo o universo de informação disponível na rede, a comunicação e interatividade também estãopresentes.O celular, meio de comunicação e informação, conforme sua evolução, passou a ter novas ferramentas e aplicativos, ampliando possibilidades e desafios.

A proibição do celularpelo professorem sala de aula, conforme Palagi (2016), ocorre por consequência de diversos fatores, em que o conflito com a tecnologia móvel, à falta de conhecimento e domínio tecnológico por parte do professor, levam a situações de desconforto. Professores edireção,frequentemente,sentem-se incomodados com o uso do aparelho móvel pelo estudante. Incômodo que causa mal-estar e conflito.

A proibição aparenta ser a melhor opção e,geralmente, adotada, ao invés da discussão coletiva.O aluno é excluído de discussões importantes da escola, mesmo sendo o principal afetado das decisões. Por falta de diálogo, o assunto em pauta sobre a proibição do celular, discutido e decido pela direção, em conjunto com professores e equipe pedagógica, é imposto aos educandos, restando somente a alternativa de aceitar e acatar as regras estabelecidas pela instituição de ensino. 
O conteúdo disponível na internet, aplicativose jogos, são fatores que favorecem e aumentam a problemática sobre o uso do celular nas escolas. Ao invés de propor soluções e diálogo em comunidade, o professor prevalece da situação mais fácil, a proibição. Mesmo sabendo queo aparelho faz parte da vida de boa parte dos alunos, barrar o uso é comum nas escolas do Paraná.

A dispersão é um item importante e deve ser levada em consideração, pelo fato de ocorrer em diversos fatores: o primeiro trata-se do momento, em que o educando não tem interesse pelo conteúdo explanado na aula e seu refúgio é acessar suas redes sociais, como os exemplos clássicos,Facebook e Whatsapp, além de navegar na internet. Em um segundo momento, a dispersão ocorre propositalmente pelo aluno que, de acordo com Costa (2016) não sente parte da escola.

A dispersão é vista e encarada como um problemae, o celular, deve ser proibido, essa é a decisão convincente. O professor não consegue incorporar o aparelho nas aulas para fazer uso nas atividades propostas e utiliza o recurso apenas como fonte de pesquisa na internet (ALTOÉ, 2009).

Ocelular, meio decomunicação e informação, pode ser muito aproveitado pela educação.Excluí-lo, de fato, não é a melhor opção, diante de uma sociedade conectada, que faz uso constante do dispositivo móvel, desde o lazer até as atividades do setor produtivo.Não se trata apenas de um meio de comunicação responsável pela atividade básica de realizar chamadas, mas de um meio de comunicação e informação que estabelece conexões, reduz barreirase aumenta a troca de informações entre pessoas. Basta que o dispositivo seja conectado à internet, por meio do $3 \mathrm{G}^{1}$ ou $\mathrm{Wi}-\mathrm{Fi}^{2}$, para expandir as possibilidades de exploração de comunicação, informação e conhecimento.

\footnotetext{
1 Terceira Geração. "Os sistemas $3 G$ utilizam como técnica de transmissão digital, o CDMA ou tecnologia de acesso múltiplo por divisão em código. Essa tecnologia consiste na transmissão das informações de modo que todos os usuários utilizem a mesma faixa de frequência [sic] durante todo o intervalo de tempo" (MAKLUF, 2011, p. 33).

2"Foi uma marca licenciada originalmente pela (Wi-Fi Alliance) para descrever a tecnologia de redes sem fio embarcadas (WLAN) baseadas no padrão IEEE (InstituteofElectricalandEletronicsEngineers)" (FERREIRA, 2013, p. 17).
} 
Estudar a educação face às tecnologias é importante para designar a função que o celular pode desempenhar em sala de aula, considerando o crescimento acelerado e a utilização do dispositivo móvel por crianças e adolescentes nas escolas. É fundamental a aceitação e buscar inserir novas práticas de ensino vinculadas ao uso do aparelho móvel como ferramenta de ensino.

Nesse sentido, assume como problema de pesquisa:o celular pode ser utilizado como instrumento pedagógico eficiente no estado do Paraná?Trata-se de um estudo de caso e pesquisa bibliográfica, realizada por meio de teses de doutorado, dissertações de mestrado e artigos científicos, com base no banco de dados da Capes, com o objetivode discutir a utilização do celular em sala de aula como recurso pedagógico, de acordo com a lei estadual $n^{0} 18.118 / 2014-$ PR. Além disso, apresentar ferramentas disponíveis no celular que podem ser utilizadascomo instrumentos pedagógicos, capazes de potencializar o processo de ensino e aprendizagem.

\section{CELULAR}

O número de usuários de celular no Brasilcresce a cada ano. O dispositivo móvel tem sido utilizado como ferramenta de trabalho e de lazer, ficando quase impossível a exclusão do aparelho. A cada ano, pessoas compram novos modelos, lançados pelas marcas fabricantes, em busca de estar sempre atualizadas com o que há de melhor em tecnologia.

Atualmente, o País tem 198 milhões de celulares em uso, o que representa um crescimento de $17 \%$ na comparação com os dados de 2016. Ainda de acordo com a pesquisa, entre notebooks, tablets e desktops, o Brasil tem também 162,8 miIhões de computadores em funcionamento - um crescimento de $5 \%$ com relação ao levantamento de 2015 . E deve chegar até dezembro deste ano a 166 milhões de computadores em uso, incluindo no cálculo cerca de 33 milhões de tablets (OSELAME; SANTOS; SILVA, 2017, p. 02).

Os números relacionados ao celular no Brasil representam a expressividade da tecnologia, à disposição de quase toda a população, a grande maioria, 
conectadas à internet ${ }^{3}$ por meio da tecnologia $3 G$ e WI-FI. Sendo que, muitas famílias possuem mais que um aparelho móvel por pessoa.

Divulgada em abril de 2017 pela FGV, a $28^{a}$ edição da pesquisa anual de Administração e Uso de Tecnologia de Informação nas Empresas aponta que até o final deste ano o Brasil terá a média de um smartphone por habitante. A estimativa é de que até outubro o número chegue a 208 milhões de aparelhos (OSELAME; SANTOS; SILVA, 2017, p. 02).

Nesse contexto, a criança nasce inserida na tecnologia e tem a aquisição do conhecimento e domínio tecnológico facilitado, uma vez que, o acesso ao celular ocorre de modo natural e a utilização é feita gradativamente. Dessa forma, "os seres humanos não nascem simplesmente dentro da linguagem como um código maior; eles crescem dentro dela, são formados por ela, ajudam formá-la, tanto o homem como a mulher [...]" (STAM, 1992, p. 93).

A proibição do celular nas escolas tem sido legalmente estabelecida em alguns estados brasileiros.

Vários estados brasileiros já estabeleceram legalmente a proibição do uso de celulares pelos estudantes nas escolas. $O$ primeiro foi São Paulo. Outros estados da federação também proíbem o uso de celulares nas salas de aula: Rio de Janeiro, Ceará, Brasília, Santa Catarina, Mato Grosso do Sul, Rondônia entre outros. O acúmulo desse tipo de legislação proibitiva no país parece indicar que exista um consenso entre os educadores de que o uso do celular em sala de aula pode causar a distração do aluno, afetar o rendimento escolar das crianças e atrapalhar a didática dos professores (VIVIAN; PAULY, 2012, p. 03).

No Paraná, a situação também ocorre. Com base na lei estadual $n^{0}$ 18.118/2014-PR, no artigo $1^{\circ}$ : "proíbe o uso de qualquer tipo de aparelhos/ equipamentos eletrônicos durante o horário de aulas nos estabelecimentos de

3“A internet nasceu de um projeto militar norte-americano chamado Arpanet, uma rede de computadores montada em 1969 pela AdvancedResearchProjectsAgency (ARPA). Os primeiros nós dessa rede foram alguns centros universitários de pesquisa. Em 1983, o Departamento de Defesa dos EUA, preocupado com possíveis brechas de segurança, resolveu criar a MILNET, rede independente para usos militares específicos. A Arpanet tornou-se ARPA-INTERNET e foi dedicada à pesquisa. Na década de 1980, passou a se chamar Internet". (NAGUMO, 2014, p. 10). 
educação de ensino fundamental e médio no Estado do Paraná" (PARANÁ, 2014, p. 01). Com essa medida, o professor segue o que é estabelecido e proíbe o uso do celular.

É importante destacar que, a mesma lei que proíbe, também permite. Em seu parágrafo único, a lei diz que, "a utilização dos aparelhos/equipamentos mencionados no caput deste artigo será permitida desde que para fins pedagógicos, sob orientação e supervisão do profissional de ensino"(PARANÁ, 2014, p. 01).Portanto, é possível utilizar o celular, desde que seja movidoe norteado por intencionalidades pedagógicas.

O uso indevido do aparelho móvel também ocorre. Em alguns casos, ele é responsável por situações de conflitos na sala de aula, como a dispersão pelo acesso do aluno a jogos, fotos e vídeos salvos na galeria do aparelho, ligações/chamadas durante a aula, ouvir música com fone de ouvido e acesso a redes sociais, como o Whatsapp e Facebook.

Nesse sentido, a proibição ocorre com frequência, considerando que o aparelho nem sempre é visto com bons olhos pelo professor, que opta, quase sempre,pela proibição ao invés da inclusão como instrumento pedagógico. Assim,"por falta de resiliência profissional para resolver os conflitos que são provocados pela presença marcante, na sala de aula, deste aparelho móvel, proíbe-se. Vê-se na proibição a melhor alternativa para se solucionar problemas e conflitos" (SOUZA, 2017, p. 02).

\section{TECNOLOGIAS DE INFORMAÇÃO E COMUNICAÇÃO - TIC}

As tecnologias de informação e comunicação - TIC4 têm provocado mudanças significativas, tanto na sociedade como na educação, por se tratar de ferramentas que potencializam e facilitam as atividades humanas, como no trabalho, no lazer e na educação. Segundo Palagi(2016, p. 73), "o conceito de

\footnotetext{
4 "O termo Tecnologias da Informação e Comunicação(TIC) refere-se à conjugação da tecnologia computacional ou informática com a tecnologia das telecomunicações e tem na Internet e mais particularmente na World Wide Web (WWW) a sua mais forte expressão" (MIRANDA, 2007, p. 43).
} 
tecnologia foi tratado como a junção das técnicas com a ciência".É a tecnologia responsável pela aceleração das atividades humanas, em consequência da facilidade de realização de atividades do setor produtivo, contribuindo para redução do tempo e esforço. Porém, "[...] a tecnologia nos permitiu acelerar a execução das atividades cotidianas, dando-nos a ilusão de que dominamos o tempo, quando na verdade, somos muitas vezes dominados por ele" (NAGAMINI, 2017, p. 03).

A redução de distâncias e a facilidade de comunicação entre as pessoasocorre devido a função que a internet tem desempenhado. Com ela, a distância é encurtada e as pessoas são aproximadas, podendo exercer a comunicação a um curto período.

[...] a Sociedade da Informação foi marcada pelos avanços tecnológicos e das telecomunicações que transformaram o cenário dos tempos modernos e proporcionaram interatividade provocando mudanças significativas no modo de vida entre os cidadãos conectados com as diversas informações e dando um ponto final à uniformidade e massificação [...] (SOUZA, 2017, p. 02).

O desenvolvimento da tecnologiaalterou o modo como às pessoas se relacionam, sendo que, as relações presenciais estão sendo substituídaspelasinterações virtuais. A tecnologia afetou também a educação, pois "[...] como na economia, na política, na cultura, o avanço da tecnologia está presente no setor educacional, trazendo com isso a necessidade de utilização dessa ferramenta tecnologia na aprendizagem" (SILVA, 2015, p. 20456).

Os estudantesusam a internet como meio de informação, comunicação e interatividade, buscam novas experiências e distrações, permanecendo conectados mais tempo nela do que presentes nos espaços físicos da escola.

O uso de tecnologias nas escolas vem sendo tema de estudos e pesquisas,pelo fato de se referir a um assunto relevante a sociedade e a possibilidade de utilização de tecnologias na educação como estratégia para favorecera prática pedagógica do professor. 
A utilização de certa tecnologia pode favorecer ou desfavorecer práticas específicas, inclusive o fortalecimento da troca e do diálogo que desenvolvem papel ativo na construção dos sujeitos e sua profissionalização, o que justifica a articulação do uso de tecnologias da comunicação no cenário de aulas da universidade (BARBOSA; BARCELLOS; CARVALHO, 2017, p. 03).

A conectividade e o excesso de informação são frequentes (NAGUMO, 2014), assim, os sujeitos estão cada vez mais conectados, enviam e recebem informações utilizando os meios de comunicação, principalmente, o celular conectado à internet. Segundo Moraes (2006, p. 35), "a digitalização favorece a convergência de redes e plataformas numa linguagem única, forjando a base para a hibridação das infraestruturas de transmissão de dados, imagens e sons".

O excesso de informação disponível na internet, sites e redes sociais, é um desafio a ser enfrentado, considerando que,"“...] a quantidade de material na rede tem crescido de tal forma que muitos acabam tendo dificuldade de lidar com tanta informação. Por um lado, há uma diversificação do conteúdo disponível, assim como o aumento de informações de pouca relevância" (NAGUMO, 2014, p. 12). Cabe ao professor, trabalhar na formação de um sujeito crítico, capaz de compreender a informação relevante veiculada pela mídia.

Diante do desenvolvimento tecnológico e da globalização, conforme Souza (2017), é comumexistir escolas que ignoram as tecnologias efazem uso de processos de ensino comuns, como o quadro de giz, prevalecendo o ensino de memorização de conteúdo. Porém, não basta apenas substituir os métodos de ensino tradicionais por recursos tecnológicos e permanecer a metodologia, pois a tecnologia isolada, não é capaz de inovar o processo de ensino.

UsarasTIC apenas como meio de facilitar a prática de ensino e permanecer a métodos tradicionais, giz, quadro e livro, não é o ideal. O data show é um exemplo, devido sua apropriação serrealizada, geralmente, para substituir o quadro negroe evitar o esforço de escrever. É comum o uso dessa tecnologia como meiodeexibirtextos, imagens e vídeos em tela. 
A resistência do professor face às TICtem ocorrido em virtude de diversos fatores, principalmente a falta de capacitação. Segundo Vivian ePauly (2012) são diversos os argumentos para não utilizar os meios digitais, como a falta de tempo para uma aquisição de conhecimento, o espaço precário e a falta de equipamento nas escolas, tecnologias ultrapassadas ou que não funcionam, medo de estragar os equipamentos existentes.

De acordo com Barbero (2006, p. 56), "a escola está deixando de ser o único lugar de legitimação do saber, já que há uma variedade de saberes que circulam por outros canais, difusos e descentralizados". Com a internet, informações e saberes são compartilhados pelos usuários, sem a necessidade de deslocamento até um local físico.

Nagumo (2014), por sua vez, diz que há uma distância muito grande entre a escola e a realidade dos educandos, que tem provocado um descompromisso. Com a internet, a escola tem perdido o título de detentora do saber. Seria ideal que oestabelecimento de ensino assuma o papel de tomar para si a missão de orientar seus alunos no processo do saber (NAGUMO 2014).

Novas formas de comunicação e recebimento de informação transcorrem e o modelo de ensino tradicional5passa a ser questionado, pois "vivemos num ambiente de informação que recobre e mistura vários saberes e formas muito diversas de aprender, ao mesmo tempo que se encontra fortemente descentrado em relação ao sistema educativo que ainda nos rege, organizado em torno da escola e do livro" (BARBERO, 2006, p. 56).

No modotradicional de ensino, o professor tem o domínio do saber, além de possuir autoridade máxima, sem espaço para a participação e integração nas decisões. Esse modelo de ensino deixou de ser referência e não atende mais as demandas da novageração de alunos,caracterizada por novas formas de descobrimento e aprendizagem, na curiosidade e inquietação.

\footnotetext{
5 Segundo Leão (1999, p. 187) "a abordagem tradicional do ensino parte do pressuposto de que a inteligência é uma faculdade que torna o homem capaz de armazenar informações, das mais simples às mais complexas. Nessa perspectiva é preciso decompor a realidade a ser estudada com o objetivo de simplificar o patrimônio de conhecimento a ser transmitido ao aluno que, por sua vez, deve armazenar tão somente os resultados do processo.
} 
[...] inquietação, o dinamismo e a interação dos alunos dessa nova Geração da Internet, é intensa. Os mesmos utilizam as TIC (Tecnologias de Informação e Comunicação) para se comunicar e ficarem conectados boa parte do seu tempo e assim utilizam o aparelho celular a todo o momento pelo fato deste possuir diversas ferramentas como bloco de notas, câmera fotográfica, serviço de mensagem (SMS), acesso a internet com abertura para as redes sociais, dentre outros [...] (SILVA, 2015, p. 20456).

Com o celular, o estudante passa a questionar com mais frequência o conteúdo abordado pelo professor, visto que, com o acesso à internet, pode pesquisar e aprofundar o assunto. $O$ que é dito pelo professor, nem sempre é aceito, considerando que "desde as interações midiáticas, os sujeitos-educandos questionam o professor, questionam seus saberes enciclopédicos esvaziados de significado, diante da abundância representacional e policromática dos ecossistemas comunicativos" (OROZCO, 2006, p. 96).

O modelo de ensino tradicional, em que o professor é detentor do saber, não atende mais as necessidades da nova geração. Segundo Freire (1997, p. 69) "a educação é comunicação, é dialógica, na medida em que não é a transferência de saber, mas um encontro de sujeitos interlocutores que buscam a significação dos significados".

Segundo Neto (2013, p. 01), "o papel do docente atual deve ir muito além, ele deve ser o mediador entre o conhecimento, a experiência de vida, o mundo em geral, e os seus discentes". Além disso, "a mera exposição das audiências à imagem nas diferentes e possíveis telas supera quantitativamente sua exposição aos quadros-negros e às figuras dos professores nas salas de aula" (OROZCO, 2006, p. 96).

A mídia impressa, não perdeu sua credibilidade ao longo do tempo, mas houve uma redução no consumo, principalmente o jornal eo livro, pois "antes, o livro que o professor trabalhava na sala de aula tinha a "última palavra". Agora, a última imagem está na tela e a última palavra quem tem são os sujeitos-audiência, e seus olhos" (OROZCO, 2006, p. 96). Um dos fatores para a redução 
do consumo da mídia impressa ocorre em razão do surgimento de novas tecnologias de informação e comunicação.

A internet traz novas possibilidades de comunicação, informação e interatividade ao permitir ao usuário a convergência de várias mídias em um único meio de comunicação, como o rádio, TV e jornal, presentes no celular e computador.

A convergência materializa-se na terceira geração da telefonia móvel, que permite a um celular conectar-se à Internet; ser utilizado como câmera e filmadora digital, MP3 e rádio FM; disponibilizar correio eletrônico, mensagens, noticiários, horóscopo, jogos eletrônicos, mapas e filmes, além de capturar e enviar imagens (MORAES, 2006, p. 35).

A forma como o estudante se relaciona e tem recebido informação, principalmente com a internet, deve ser refletida e pensada como um argumento para mudanças na prática de ensino. Muitas vezes, ele não sente parte da escola e a metodologia de ensino utilizada pelo professor não desperta interesse. Além disso, "[...] há uma distância entre a escola e a realidade dos alunos que tem gerado uma apatia e descompromisso desses estudantes. Com a internet, a escola tem perdido progressivamente o monopólio da criação e transmissão do conhecimento" (NAGUMO, 2014, p. 24).

A inclusão das TIC em sala não significa que o professor irá perder sua autonomia, tão pouco ser substituído. O professor desenvolve importante papel na educação e as tecnologias em si, apropriadas de modo incorreto, não são capazes de inovar e resolver o processo de ensino e aprendizagem. Para isso, seu uso deve ser feito de forma consciente e planejada.

Os docentes manifestam um terror profundo de serem substituídos pelas novas tecnologias de informação colocadas a serviço de objetivos de aprendizagem. $E$ as instituições educativas acabam por não compreender a magnitude da mudança, e insistem teimosamente em continuar com uma visão reducionista que só repara no aspecto instrumental, tanto de mídias quanto de tecnologias. Não é equipar de máquinas as escolas a única alternativa para abreviar o desafio, como insistiram muitos ministérios de educação latino-americanos. Na verdade, debater 
e repensar os motivos da educação e da comunicação em uma grande mudança de época com a atual é o que necessitamos continuar fazendo (OROZCO, 2006, p. 97).

Por meio de políticas públicas, os estados brasileiros tem buscado fornecer os equipamentos tecnológicos às escolas, mas de forma limitada. São enviados computadores com recursos mínimos em pequena quantidade, incapaz de atender a demanda de alunos da instituição. É relevante a ampliação de recursos tecnológicos, em busca de melhorar a estruturadas escolas brasileiras, para que assim, novas práticas de ensino e aprendizagem sejamconsideradas pelo professor, principalmente pela inclusão das tecnologias de informação e comunicação.

\section{INTERNET NO CELULAR}

A ausência de interesse e perspectiva do estudante pela escola tem aumentado nos últimos anos, por não se sentir parte da escola.Geralmente, as decisões com relação ao ensino são impostas e não discutidas. Conteúdo ultrapassado, que não faz parte da realidade social, também contribui para a falta de perspectiva, pois não consegue atribuir sentido e relação ao que é estudado. É importante que o conteúdo seja pautado com base na realidade social da classe, para que não se torne vago e não vinculado a realidade social da instituição de ensino.

[...] no processo de aprendizagem, só aprende verdadeiramente aquele que se apropria do apreendido, transformando-o em apreendido, com o que pode, por isso mesmo, re-inventálo; aquele que é capaz de aplicar o aprendido-apreendido a situações existenciais concretas. Pelo contrário, aquele que é "enchido" por outros de conteúdos cuja inteligência não percebe, de conteúdos que contradizem a própria forma de estar em seu mundo, sem que seja desafiado, não aprende (FREIRE, 1997, p. 13).

A exclusão do aparelho móvel pelo professor ocorre devido ao uso incorreto, propício a trazer problemas à aprendizagem ao invés de favorecê-la, pois 
"[...] o argumento principal é a de que o uso de celulares pode tirar a atenção dos alunos prejudicar o andamento das aulas (NAGUMO, 2014, p. 69). O celular pode provoca nos estudantes o desvio de atenção, dispersão e acesso a conteúdo indevido. O aparelho móvel é visto de forma negativa e acredita-se que é inadequado ao ambiente escolar e pode provocar a distração dos estudantes.

[...] utilizam o aparelho celular a todo o momento pelo fato deste possuir diversas ferramentas como bloco de notas, câmera fotográfica, serviço de mensagem (SMS), acesso à internet com abertura para as redes sociais, dentre outros, promovendo e contribuindo para a distração dos alunos e comprometendo a atenção requerida pelo o professor durante as aulas ( SILVA, 2015, p. 20456).

O celular permite ao usuário o envio e recebimento de informação em momento instantâneo, em alta velocidade, dependendo do acesso à internet. Com ele, o sujeito tem à disposição a informação em tempo real, se mantendo sempre bem informado, pois o "[...] telefone móvel permite acesso instantâneo e fácil à informação sobre o que está acontecendo em qualquer lugar do mundo, diluindo assim as fronteiras" (SOUZA, 2017, p. 02).

O professor, não consegue identificar as "[...] potencialidades da adoção do celular em sala de aula, como ferramenta tecnológica que pode agregar significação ao estudo dos gêneros textuais e também incrementar o gosto pelas leituras, aproximando os conteúdos curriculares à realidade social do aluno" (SOUZA, 2013, p. 02).

O aparelho móvel modifica a realidade social, pois "[...] a era dos dispositivos móveis e portáteis transforma a mobilidade social, cria novos processos de controle informacional, reconfigura as noções de tempo e espaço e reestrutura as dinâmicas entre indivíduo e espaço urbano" (OSELAME; SANTOS; SILVA, 2017, p. 03).

É importante trabalhar a disciplina do sujeito educando, diálogo entre professor e aluno sobre o uso correto do celular, como um instrumento de 
aprendizagem.Trata-se de um meio tecnológico importante a educação, tudo depende do uso correto e planejado, vinculado aos objetivos e conteúdo da aula.

\title{
5 RESULTADOS
}

As tecnologias de informação e comunicação podem mudar a visão do estudante perante a escola. De acordo com Silva (2015, p. 457), "o uso de tecnologias em salas de aula pode contribuir para a construção de novos saberes que favoreçam ao indivíduo uma visão mais ampla de mundo com mais criatividade, criticidade e com amplos potenciais para o descobrimento".

O professor ao utilizar tecnologias aumenta a sua responsabilidade sobre a formação do estudante e seu papel passa a ser mediador do conhecimento, orienta e faz a mediação entre o saber e estudante. $O$ educador trabaIha na construção da autonomia dos integrantes da classe, o mesmo irá sentir envolvido e integrante da escola, buscando o conhecimento individualmente por meio de orientação do professor.

\begin{abstract}
O educador em sala de aula deve formular seu discurso como um produtor de informação que conta com a capacidade de pressuposição e inferência do seu recebedor. Ou seja, ao docente cabe justamente o estímulo à curiosidade dos discentes. Ele deve deixar aqueles que o ouvem dar o "passo final" rumo à compreensão do assunto que esteja sendo tratado (NETO, 2013, p. 02).
\end{abstract}

A comunicação e interatividade em sala são importantes para a formação, estimulam o conhecimento, a descoberta de saberes, tendo em vista que "toda comunicação impõe um aprendizado da linguagem do outro, uma espécie de tradução, ou de acordo, com o significado nos limites do nosso conjunto pessoal de linguagens de outra pessoa" (STAM, 1992, p. 13).

A partir do momento em que o educando está envolvido com a troca de experiência possibilita a aquisição de novos saberes de forma prazerosa, pois "o processo de aprendizagem, próprio do paradigma que possibilita a tecnolo- 
gia informacional, ocorre por descobrimento (exploração), não por imitação (reprodução), como foi o caso predominante até agora em muitas culturas e na própria educação escolar" (OROZCO, 2006, p. 97).

Segundo Freire (1997, p. 81) "a tarefa do educador, então, é a de problematizar aos educandos o conteúdo que os mediatiza, e não a de dissertar sobre ele, de dá-lo, de estendê-lo de entrega-lo, como se se tratasse de algo já feito, elaborado, acabado, terminado".

A lei $n^{\circ} 18.118 / 2014-P R$ proíbe o uso do celular nas escolas do Paraná, porém, em seu parágrafo único, a lei diz que, "a utilização dos aparelhos/equipamentos mencionados no caput deste artigo será permitida desde que para fins pedagógicos, sob orientação e supervisão do profissional de ensino" (PARANÁ, 2014, p. 01).

O celular provoca mudanças na sociedade, bem como no ensino. De acordo com Souza (2017, p. 01)“a presença do telefone celular induz a profundas mudanças na sociedade e na maneira de organizar o ensino para aprender e saber sobre o mundo".

De acordo com a UNESCO,

[...] os aparelhos móveis, presentes em todos os lugares - especialmente telefones celulares e, mais recentemente, tablets são utilizados por alunos e educadores em todo o mundo para acessar informações, racionalizar e simplificar a administração, além de facilitar a aprendizagem de maneiras novas e inovadoras (UNESCO, 2013, p. 7).

Com base no problema de pesquisa, é possível levantar alguns benefícios quanto ao uso do celular como instrumento pedagógico eficiente. São os levantamentos:

- [...] pode se converter em uma boa ferramenta pedagógica que agrega maior dinamismo e interatividade ao conteúdo curricular, especialmente no que concerne ao registro de fotos, imagens, ambientes, filmagem e anotações (LOPES; PIMENTA, 2017 p. 61). 
- [...] os aparelhos podem oferecer recursos de leituras, pesquisas, estudo e atividades pedagógicas como aprender ou praticar uma segunda língua, por exemplo, por meio da utilização de aplicativos desenvolvidos especialmente para este fim (LOPES; PIMENTA, 2017 p. 61). Nesse caso, pode-se citar o aplicativo de ensino de idiomas, Duolingo.

- [...] os celulares são verdadeiros computadores portáteis interligados na internet, com inúmeros recursos internos, capazes de filmar, tirar fotos, produzir montagens, gravar o áudio que o usuário desejar, além de oferecer uma grande variedade de acesso aos aplicativos, programas criados por pessoas jurídicas para atender necessidades de todo tipo, inclusive, educativas (LOPES; PIMENTA, 2017 p. 59-60).

- O uso da tecnologia é essencial em sala de aula, pois permite aos alunos acompanhar e participar da evolução da tecnologia que cresce de forma rápida e contínua, POIS facilita a compreensão dos alunos nos conteúdos mais simples até os mais complexos, possibilita maior interesse em participar e aprender devido a aula se tornar prazerosa e, prepara-os para a realidade do mercado de trabalho que cada vez mais exige conhecimento mínimo na área tecnológica (PACHECO; PINTO; PETROSKI, 2017, p. 6369).

- [...] câmera fotográfica, câmera de filmagem, serviço de mensagem (SMS), bluetooth, bloco de notas, dispositivo de acesso a internet dentre outras ferramentas, as quais bem orientadas e utilizadas podem diminuir o conflito existente entre a atenção requerida pelo professor e a atração de utilizar o equipamento nos espaços educativos formais [...]" (SILVA, 2015, p. 20458).

- [..] em relação ao engajamento dos estudantes, tendo em vista que se sentem mais motivados a participar das aulas (THOMAS; O'BANNON; BOLTON, 2013, apud p. ZUIN;ZUIN, 429).

Cabe ao professor o uso do celular por meio de estratégia planejada e consciente, uma vez que, "[...] é necessário explorar as diferentes linguagens em aula e incentivar o aprendizado da nova geração por meio dos recursos que despertam o interesse pelo conhecimento" (COSTA, 2017, p. 03).

É necessário construir debates nas escolas para formulação de um ambiente que, a priori, repense a inclusão das tecnologias digitais, em especial o 
celular, visando o aperfeiçoamento do processo de ensino, culminando em uma abordagem reflexiva, aliada ao conteúdo abordado pelo professor.

\section{CONSIDERAÇÕES FINAIS}

Por não saber como usar o celular em sala de aula e identificar suas potencialidades a aprendizagem, a proibição acaba sendo a opção adotada, uma vez que,"ao não saber dar significado ao telefone móvel, cria-se conflitos, não sabendo resolver os conflitos, proíbe-se" (SOUZA, 2017, p. 13).

A grande quantidade de alunos usuários de celulares nos últimos anos, colabora para o desdobramento de atenção a problemática sobre o uso do celular em sala de aula, sabendo que é importante a escola compreender o contexto social do estudante.

Transpor as barreiras ao uso do celular no espaço escolar é um desafio, em virtude da comunicação e da troca de informação que se faz constante por meio do aparelho conectado à internet. Ignorar o acesso e proibir não é a meIhor opção, na verdade, só ocasiona irritação e problematização em aceitação e respeito ao regimento interno da instituição de ensino.

O uso do celular como instrumento pedagógico é um desafio importante a ser enfrentado, não somente pelas escolas do estado do Paraná, mas de todos os estados brasileiros. É relevante que o distanciamento entre celulare professor seja reduzido, pois juntos podem proporcionar a construção de uma aprendizagem coletiva eficiente.

\section{REFERÊNCIAS}

ALTOÉ, A., FUGIMOTO, S. M. A. Computador na educação e os desafios educacionais. IX Congresso Nacional de Educação - EDUCERE, III Encontro Sul Brasileiro de Psicopedagogia. 26 a 29 de Outubro de 2009.

BARBERO, Jesús Martín. Tecnicidade, Identidade, Alteridades: Mudanças e opacidades da comunicação no século. IN: MORAES, Dênis de. Sociedade midiatizada. Rio de Janeiro: Mauad, 2006. (p. 51-80).

BARBOSA, Maria Irene de Castro; BARCELLOS, Daniela Menezes Neiva; CARVALHO, Maria Cláudia da Veiga Soares de. 'Pode ser por Whatsapp?' Aspectos intera- 
cionais nas mensagens de aplicativos de celular no contexto da disciplina de educação nutricional. Anais... INTERCOM - Sociedade Brasileira de Estudos Interdisciplinares da Comunicação $40^{\circ}$ Congresso Brasileiro de Ciência da Comunicação. Curitiba-PR, 04 a 09 set. 2017.

COSTA, M. C. C. Educomunicador é preciso. Disponível em: http://www.usp.br/nce/ wcp/arq/textos/7.pdf Acesso em: 25 fev. 2018.

COSTA, Suéller. A autoria em sala de aula: o incentivo à participação discente e docente por meio de projetos que envolvem a produção midiática para a educação. Anais... INTERCOM- Sociedade Brasileira de Estudos Interdisciplinares da comunicação $40^{\circ}$ Congresso Brasileiro de Ciência da Comunicação. Curitiba-PR, 04 a 09 set. 2017.

FERREIRA, Jeferson Luiz Miranda. Segurança em Redes sem Fio. 2013. Monografia (Especialização em Configuração e Gerenciamento de Servidores e Equipamentos de Redes). Universidade Tecnológica Federal do Paraná. Curitiba, 2013.

FREIRE, P. Extensão ou comunicação? Rio de Janeiro: Paz e Terra, 1997.

LEÃO, Denise Maria Maciel. Paradigmas contemporâneos de educação: escola tradicional e escola construtivista. Cadernos de Pesquisa. n 107, p. 187-206, julho/1999.

LOPES, Priscila Almeida; PIMENTA, Cintia Cerqueira Cunha. O uso do celular em sala de aula como ferramenta pedagógica: Benefícios e desafios. Revista Cadernos de Estudos e Pesquisa na Educação Básica, Recife, v. 3, n. 1, p. 52 - 66, 2017.

MAKLUF, Cibele Abreu. Análise de tecnologias 3G visando à estruturação do canal de retorno da TV digital. Dissertação (mestrado) - Universidade Estadual de Campinas. Faculdade de Engenharia Elétrica e de Computação, 2011.

MIRANDA, Guilhermina Lobato. Limites e possibilidades das TIC na educação. SISIFO - Revista de Ciências da Educação. N. ${ }^{\circ}$ 03, maio/ago. 2007.

MORAES, Dênis de. A tirania do fugaz mercantilização cultural e saturação midiática. IN: MORAES, Dênis de. Sociedade midiatizada. Rio de Janeiro: Mauad, 2006. (p. 33$50)$.

NAGAMINI, Eliana. O Uso do Aplicativo Whatsapp: Tempo de escrita/oralidade de alunos do ensino fundamental.Anais... INTERCOM - Sociedade Brasileira de Estudos Interdisciplinares da Comunicação $40^{\circ}$ Congresso Brasileiro de Ciência da Comunicação. Curitiba-PR, 04 a 09 set. 2017.

NAGUMO, Estevon. $O$ uso do aparelho celular dos estudantes na escola. Dissertação (mestrado) - Universidade de Brasília. Faculdade de Educação. Programa de Pós-Graduação em Educação, 2014.

NETO, Gabriel Lage. Tecnologias, comunicação e educação: a utilização da internet como extensão do relacionamento entre docentes e discentes em sala de aula. Anais... INTERCOM - Sociedade Brasileira de Estudos Interdisciplinares da comunicação XXXVI ${ }^{\circ}$ Congresso Brasileiro de Ciência da Comunicação. Manaus-AM, 04 a 07 set. 2013. 
OROZCO, Guillermo. Comunicação social e mudança tecnológica: Um cenário de múltiplos desordenamentos. IN: MORAES, Dênis de. Sociedade midiatizada. Rio de Janeiro: Mauad, 2006.

OSELAME, Mariana Corsetti; SANTOS, Leandro dos Santos; FELIPE, Matheus da Silva. Celular na sala de aula: desafios e possibilidades para o ensino do telejornalismo. Anais... INTERCOM - Sociedade Brasileira de Estudos Interdisciplinares da comunicação $40^{\circ}$ Congresso Brasileiro de Ciência da Comunicação. Curitiba-PR, 04 a 09 set. 2017.

PACHECO, Mariã Aparecida Torres; PINTO, Leandro Rafael; PETROSKI, Fábio Roberto. O uso do celular como ferramenta pedagógica: uma experiência válida. EDUCERE, XII Congresso Nacional de Educação, PUC-PR, Curitiba, 2017.

PALAGI, AnaMaria Marques. Formação de Professores em tecnologias digitais em diálogo com as políticas públicas no estado do Paraná. 2016. Tese de Doutorado (Doutorado em Educação) - Centro de Ciências Humanas. Universidade do Vale do Rio dos Sinos - UNISINOS, São Leopoldo, 2016.

PARANÁ. Lei $n^{\circ} 18.118 / 2014$, de 24 de junho de 2014. Dispõe sobre a proibição do uso de aparelhos/equipamentos eletrônicos em salas de aula para fins não pedagógicos no Estado do Paraná. Assembleia legislativa do Paraná. Curitiba, PR, 24 de jun. 2014. Disponível em: http://www.comunicacao.mppr.mp.br/modules/noticias/article.php?storyid=11862. Acesso em: 25 fev. 2018.

SANTOS, José Ozildo dos; SANTOS, Rosélia Maria de Souza dos. O uso do celular como ferramenta de aprendizagem. Pombal, 2014. REBES. V. 4, n. 4, out, dez. p. 1-6.

SILVA, Dilma Oliveira da. O uso do celular no processo educativo: Possibilidades na aprendizagem. Anais... EDUCERE. XII Congresso nacional de educação, PUCPR, 26 a 29 out. 2015.

SOUZA, Josenilda Martins de. O uso do celular: por que proibir é a melhor opção? Anais... $6^{\circ}$ simpósio hipertexto e tecnologia na educação. $2^{\circ}$ colóquio internacional de educação com tecnologias. ISSN: 194-1175, 2017.

STAM, Robert. Bakhtin: da teoria literária à cultura de massa. São Paulo: Editora Ática S. A., 1992.

UNESCO PolicyGuidelines for Mobile Learning. Organização das Nações Unidas para a Educação, a Ciência e a Cultura (UNESCO). Paris, France, 2013. Disponível em: <http://creativecommons.org/licenses/by-nc-nd/3.0/igo/> Acesso em: 25 fev. 2018.

VIVIAN, Caroline Deprá; PAULY, Evaldo Luis. O uso do celular como recurso pedagógico na construção de um documentário intitulado: Fala Sério! Colabor@ - Revista Digital da CVA, ISSN 1519-8529. Volume 7, Número 27, núm. de p., fev. 2012.

ZUIN; Vânia Gomes; ZUIN, Antônio Álvaro Soares. O celular na escola e o fim pedagógico. Educ. Soc., Campinas, v. 39, nº. 143, p.419-435, abr.-jun., 2018. 